\title{
地域ナレッジの共有と集落特性の関係性
}

\author{
山口創（神戸大学大学院農学研究科） \\ 中塚 雅也（神戸大学自然科学系先端融合研究環）
}

\section{The Relationship between Regional Knowledge and Village Characteristics}

\author{
So Yamaguchi (Kobe University) \\ Masaya Nakatsuka (Kobe University)
}

Aging problems and depopulation in rural areas are said to lead to loss and deterioration of regional knowledge.

This study discusses (1) the level of knowledge acquisition among different age groups in villages, (2) the relationship between the level of knowledge and village characteristics, (3) the main factors of village characteristics that contribute to knowledge acquisition.

A total of 232 questionnaires were collected from 16 villages in Sasayama city, Hyogo prefecture, to

\section{1. 背景と目的}

農村地域では, 過疎・高齢化や混住化等の進展に ともない, これまでの地域社会システムの維持が困 難になりつつある．また，次第にす寸む高齢者のリ タイアは，同時に，そらした人々がもつ地域に根ざ した知識（地域ナレッジ）を失ら過程ともいえる。 地域の資源管理や伝統行事, 自治運営に関する知 識は, 地域社会を維持, 管理していく上で必要不可 欠であり，これまで世代間で伝承，更新されてきた。 しかしながら, 近年の農村社会環境の急激な变化は, こうした知識管理を困難にする可能性があり, 既往 の研究に捛いても, その問題は指摘されている.

具体的な研究としては，世代や生活歴によって住 民が重要と認識している知識と実際の所有との間に ギャップがあること, 地域づくりワークショップが 知識集積, 知識共有の場として機能寸る可能性があ ることを指摘した中塚ら [1] や，ため池管理を事例 に，ため池管理知識の役職間，世代間での偏在を明 らかにした深町ら [2]，また住民の知識所有，地域 社会に打ける活用実態に関する分析から，高齢者の explore the villagers' knowledge on the natural environment, culture, and village life.

Three hypotheses were tested: (A) active villages have a higher level of knowledge acquisition; (B) larger villages have a higher level of knowledge acquisition; and (C) depopulated villages have a lower level of knowledge acquisition.

The results differed among age groups, and the age group of 60-70 had tendency of (A) and (B), while the group of $40-50$ only showed (B).

豊富な知識が潜在化していることを指摘した菅原ら [3]の研究がある.これらの研究では, ともに次世 代への知識継承に危機を示しながら，その対策とし て暗黙知の形式知化や，知識共有の場を設ける必要 性を指摘している ${ }^{1)}$. また，先行研究の特徵は，住 民の個人属性と知識所有の関係を明らかにした点に ある、しかし，野中らが知識は場を通して共有され ると指摘 ${ }^{2}$ するよらに知識は, 個人の経験の積み重 ね訪けでなく，他者から獲得されるものであり，地 域活動への参加や他住民との交流など地域の社会的 な特性が知識所有に影響すると考えられる。しかし， これまで, 地域間に抢ける住民の知識所有の差異は 抢らか，地域の社会的な特性と住民の知識所有の関 係に着目した研究はない，両者の関係を明らかにす ることは，個人的な問題と思われがちな知識におい て，集落という地域社会のもつ意味を再考する契機 となり，今後の農村地域に打忊知識管理のあり方 を考光る上で, 重要な視点を提示する可能性がある.

なお, 本稿では地域ナレッジを「農村集落の自然, 社会に関係づけられ，継承されてきた知識」と限定 
的に定義して以下にて用いる ${ }^{3)}$.

\section{2. 調査地概要ならびに研究の方法 (1) 調査地概要}

調査地は, 兵庫県篠山市である. 篠山市は兵庫県 の中東部に位置し, 人口約 43,000 人 (平成 22 年), 約 200 集落からなる. 主な産業は農業・観光業であ り, 丹波黒の産地として有名である. 市の大部分が 農業地帯であるが，大阪や神戸まで車や電車で 1 時 間から 1 時間半といら好立地から, 市の中心部では, 宅地開発が進及新住民の流入が抢こっている地域も ある. しかし, 一方で, 周辺地域を中心に, 過疎, 高齢化の問題も急速にすすんで打り, 知識の衰失が 懸念される。本稿では, 農村生活や, 自然環境に密 着した地域ナレッジを扱ら特性上, 篠山市のなかで も農業集落が集まる, 城東地区, 多紀地区, 西紀地 区を対象とした。そして，これらのうち 23 集落を 調査対象集落として定めた.

\section{(2) 研究の方法}

本稿では, 先行研究の成果から, 地域ナレッジの 共有や継承は, 地域の住民活動の状態や人口動態に 関係すると考光，(1）集落の人口規模が大きい地域 では地域ナレッジは共有されやすい(得やすい). (2) 集落の人口減少が激しい集落では地域ナレッジは共 有されにくい（得にくい）．（3）住民活動が活発な 集落では地域ナレッジは共有されやすい（得やす い), の三つを仮説として設定した.

分析には，二つのデータを用いた，一つは，集落 単位での住民アンケート調査の結果に基づく住民の 地域ナレッジの得やすさと集落活性度, もら一つは, 農業センサス集落カード, 篠山市統計書（平成 21 年度）用いた集落毎の人口動態と人口規模である.

アンケート調査では, 集落住民の地域ナレッジの 共有の程度 (得やすさ), 集落活動の活性度を把握 することを目的として実施した. 地域ナレッジの指 標としては, 農業や地域資源の利用・管理に関係す る項目 5 項目と, 文化や慣習, 組織など地域生活に 関する 4 項目を設定し (表 1 参照)，それぞれにつ いて，「どの程度知りやすいですか（または，知っ ていますか)」と，5段階評価（5：いつでも知孔る， 4:やや知りやすい, 3: ゙゙ちらでもない, 2:やや 知りにくい, 1 : 非常に知りにくい) で尋齐た。 また, 集落活動の活性度は，「あなたの推まいの集落で
表 1. 地域ナレッジの調査項目

\begin{tabular}{c|l}
\hline 分野 & \multicolumn{1}{|c}{ 調查項目 } \\
\hline \multirow{5}{*}{ 資源管理 } & 農業経営や農業生産に関する知識 \\
& 山林の管理方法 \\
& 畦や水路、農道などの保全方法 \\
& 橖や竹など自然素材の利用方法 \\
& 魚や虫、木の実が取れる場所 \\
\hline \multirow{5}{*}{ 地域生活 } & 伝統的な手料理の方法 \\
& イエや親戚関係の行事やしきたり \\
& 地域の祭事や年中行事のやり方 \\
& 自治活動を円滑におこなう方法 \\
\hline
\end{tabular}

は，集落活動はどの程度活発ですか」と直接的に尋 ね, こちらも 5 段階評価（5：非常に活発，4：やや 活発，3:どちらでもない，2:あまり活発でない，1: まったく活発でない）で尋㸚た ${ }^{4}$.

調查は, 23 集落 622 戸に対し, 世帯主以外の回 答も想定し, 各戸 2 部の合計 1244 部配布した. 配 布にあたっては，各集落の農政協力員に在住集落へ の配布を依頼し，郵送にて回収した。結果，280 部 の回答を得たが（回収率 22.5\%)，集落単位の分析 をすすめる上で，妥当性を高めるため，回収率が $20 \%$ 未満の集落を除外し，最終的に 232 部，16 集 落を分析対象とした。な报，調査は 2008 年 11 月下 旬から 12 月上旬にかけて実施した.

分析では, アンケート調査で得た地域ナレッジに ついて因子分析を执こない，まず，その因子得点を， 集落毎に比較した，その上で，集落毎の平均因子得 点をもとに，クラスタ一分析を扣こない，集落の類 型化を沶こなった（40・50 代，60・70 代の 2 つの 年代別） ${ }^{5)}$. そして，統計資料，アンケート調査の 結果に基づく集落特性とクロス分析を扣こなった.

\section{3. 分析結果}

\section{（1）回答者の属性}

表 2 に回答者の属性を示す。男性が $74.6 \%$ ，女性 が $25.4 \%$ と多くを男性が占めていた，年代では，30 代以下が $8.3 \% ， 40$ 代が $11.1 \%$ と若年層の割合が低 かった．一方， 60 代が $26.9 \% ， 70$ 代が $22.6 \%$ と 60 代以上の割合が高い構成となり，高齢者が活動の主 体となっている農村の特性がこの結果からも示され た。また，農業との関係をみると，半数以上が兼業 農家といら結果となった。

\section{（2）地域ナレッジの分類}

まず，因子分析による地域ナレッジの分類を行っ 
表 2. 回答者の属性

\begin{tabular}{l|l|r|r}
\hline \multicolumn{2}{|c|}{ 属性 } & $\mathrm{n}$ & $\%$ \\
\hline 性別 & 男性 & 173 & 74.6 \\
& 女性 & 59 & 25.4 \\
\hline 年代 & $10 \cdot 20$ 代 & 7 & 2.9 \\
& 30 代 & 13 & 5.4 \\
& 40 代 & 26 & 11.1 \\
& 50 代 & 53 & 22.9 \\
& 60 代 & 62 & 26.9 \\
& 70 代 & 52 & 22.6 \\
& 80 代 & 19 & 8.2 \\
\hline 専業・ & 専業 & 81 & 35.1 \\
兼業 & 兼業 & 151 & 64.9 \\
\hline
\end{tabular}

表 3. 知識所有・知りやすさの因子分析結果（プロ マックス回転後の因子パターン)

\begin{tabular}{l|r|r}
\hline & 因子1 & 因子 2 \\
\hline 農業経営や農業生産に関する知識 & 0.365 & 0.378 \\
山林の管理方法 & 0.048 & $\mathbf{0 . 6 4 8}$ \\
畦や水路、農道などの保全方法 & 0.272 & $\mathbf{0 . 6 2 0}$ \\
葈や竹など自然素材の利用方法 & -0.111 & $\mathbf{0 . 9 5 8}$ \\
魚や虫、木の実が取れる場所 & 0.378 & 0.478 \\
伝統的な手料理の方法 & 0.365 & 0.378 \\
イエや親戚関係の行事やしきたり & $\mathbf{0 . 8 6 7}$ & 0.080 \\
地域の祭事や年中行事のやり方 & $\mathbf{0 . 9 8 3}$ & -0.111 \\
自治活動を円滑におこなう方法 & $\mathbf{0 . 8 7 4}$ & 0.028 \\
\hline
\end{tabular}

因子負荷量が 0.500 以上を太字で表記

表 4. 因子相関行列

\begin{tabular}{c|rr|r}
\hline 因子 & 1 & & \multicolumn{1}{|c}{2} \\
\hline 1 & & 1 & 0.559 \\
2 & & 0.559 & 1 \\
\hline
\end{tabular}

た. 分析には, アンケート調査の知識の得やすさに 関する 9 項目を用い, 因子の抽出には重み付けのな い最小 2 乗法を用いた。 また，因子間に相関がある ことを想定した斜交回転 (プロマックス回転)を行っ た.表 3 に因子パターン, 表4 亿因子相関行列を示す.

先に想定した 2 つ因子が抽出され，「イエや親 戚関係の行事やしきたり」(0.867),「地域の祭事や 年中行事のやり方」(0.983), 「自治活動を円滑に打 こなら方法」(0.874) が高い，第 1 因子を，「地域 活動」因子と解釈寸るとともに，「山林の管理方法」 (0.917), 「畧や農道の保全」(0.620),「菜や竹など の自然素材の利用」(0.968) が高い, 第 2 因子を「資 源管理」因子と解釈した.

\section{（3）集落別の知識の得やすさと集落類型化}

次に，集落間で地域ナレッジの得やすさの比較を
するため，「地域活動」「資源管理」それぞれの因子 について，40・50 代，60・70 代別に，各集落の平 均因子得点を求めた（図 1 , 図 2)。まず，60・70 代 では，「地域活動」は因子得点が $0.2 \sim 0.5$ までの集 落が 16 集落中 10 あり，近い数值をしめしている集 落が 3 分の 1 を占める. しかし，なかには大藤，草 の上の上らに負の值を示す集落もみられ，集落間で 少なからず差があることが分かった．「資源管理」 については $0.2 \sim 0.6$ を示寸集落が 6 集落ほどあり, 近い值を示しているが，大藤，佐貫谷のように -0.6 前後の值をとる集落や塩岡のように 1.0 付近をとる 集落もあり，かなり分散する結果となった

次に，40・50 代に打任る集落ごとの因子得点を 比較する. 40 • 50 代では「地域活動」「資源管理」が, ともに同じような数值をとる集落が半数注ど占めて いる。しかし，集落によってかなりばらつきがあり， ともに -0.5 前後の数值をとる集落 (佐貫谷, 春日江, 泉，宮代）や，塩岡のように，「地域活動」が -1.5 , 「資源管理」 -1.0 程度とかなり低い集落, 畑井, 大藤, 井串，草の上のように，ともに正の值を示す集落が ある。また，同一集落間で，40・50 代，60・70 代 の因子得点を比較すると，「地域活動」「資源管理」 がともに 60 ・70 代の汪らが高い集落が添とんどて あり，世代が高くなるほぼ，地域ナレッジが共有さ れるといら先行研究の知見がここでも確認された。

さらに，40・50 代，60・70 代の各集落の因子得 点を用い, クラスター分析（距離計算: ウォード法) を抏こない, 世代ごとに集落の類型化をおこなった。 表 5 に，各類型を構成する集落をまとめる．各類型 の特徵をまとめると，まず $60 ・ 70$ 代では，「地域活 動」「資源管理」の因子得点がともに高い集落（類 型 1）から，中間の集落（類型 2)，ともに低い集落 （類型 3）の 3 類型に分類された（表 6)。なお，「資 源管理」に関する地域ナレッジに類型間で差（有意 水準 $0.1 \%$ ）がみられた.

同様に 40 ・50 代の知識の得やすさから，集落を 分類すると，「地域活動」「資源管理」の因子得点が ともに高い集落（類型 $\mathrm{A}$ ), 中間の集落 (類型 B), ともに低い集落（類型 C）の 3 類型に類型化された (表 7)。また，分散分析の結果，「地域活動」が有 意水準 $1 \%$,「資源管理」が有意水準 $0.1 \%$ であり, 統計分析でも類型間で差が確認された. 


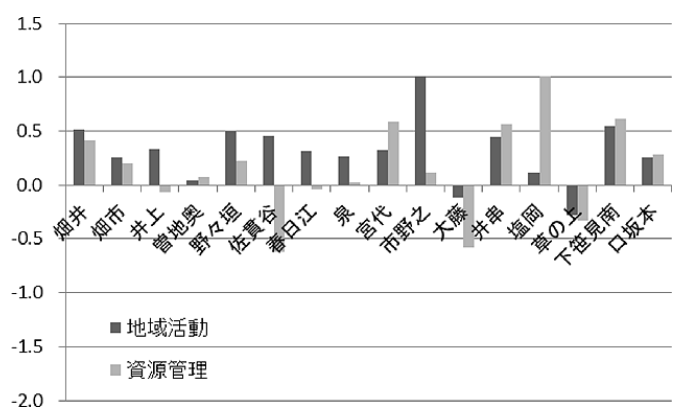

図 1. 各集落の平均因子得点 $(60 \cdot 70$ 代 $)$

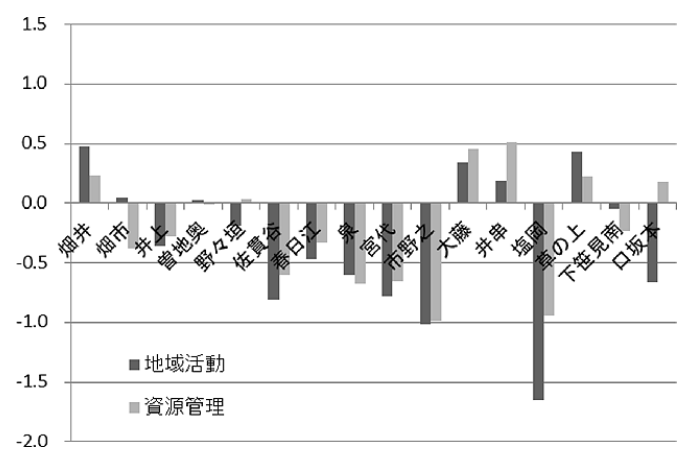

図 2. 各集落の平均因子得点 $(40 \cdot 50$ 代 $)$

\section{（4）地域ナレッジの得やすさと集落特性}

さらに，これらの類型別の地域ナレッジと集落特 性（人口規模, 人口動態, 集落活動の活性度) の関 係を分析した.「人口規模」としては戸数，人口， 農家率,「人口動態」としては, 人口増減率, 農家 人口増減率，「集落活動の活性度」は，アンケート 調査にて 5 段階評価で尋ねた結果の平均值を用い た.表 8,9 とその結果を示す.

60 •70 代については，人口規模では，「資源管理」 に関する地域ナレッジを最も得やすい類型 1 から最 も得にくい類型 3 につれて, 総戸数では 48,42 , 28 , 総人口では $140,129,85$ と人口規模が小さくなっ ている. 特に類型 3 では類型 2 の 6 割ほどの規模で あった。これらのことから，集落の人口規模が大き い集落ほど，60・70 代の住民は「資源管理」に関 する地域ナレッジを得やすくなると考兄られる。ま た, 人口動態との関係では, 人口増減率が類型 1 で $-5.0 \%$, 類型 2 が $-2.2 \%$, 類型 3 で $1.8 \%$ となり, 地域ナレッジを得やすい類型洼ど人口減少が激しい 結果となった。一方, 集落活動の活性度では, 類型 1 から類型 3 にかけてそれぞれ 3.72，3.28，3.35 と， 類型 1 と類型 2 で比較的差はみられるものの, 類型
表 5. 各集落類型の構成集落

\begin{tabular}{c|l}
\hline 類型 & \multicolumn{2}{|c}{ 集落 } \\
\hline 類型 1 & 畑井 宮代 市野々 井串 塩岡 下篠見南 \\
類型 2 & 畑市 曽地奥 野々垣 春日江 泉 口坂本 \\
類型 3 & 井上 佐貫谷 大藤 草ノ上 \\
\hline 類型 $\mathrm{A}$ & 畑井 野々垣 大藤 草ノ上 下篠見南 口坂本 \\
類型 $\mathrm{B}$ & 畑市 井上 曽地奥 佐貫谷 井串 \\
類型 $\mathrm{C}$ & 春日江 泉 宮代 市野々 \\
\hline
\end{tabular}

表 6. 各類型の平均因子得点 $(60 \cdot 70$ 代)

\begin{tabular}{l|c|ccc|c}
\hline \multicolumn{2}{l|}{} & $\begin{array}{c}\text { 類型1 } \\
(\mathrm{n}=6)\end{array}$ & $\begin{array}{c}\text { 類型2 } \\
(\mathrm{n}=6)\end{array}$ & $\begin{array}{c}\text { 類型3 } \\
(\mathrm{n}=4)\end{array}$ & P值* \\
\hline \multirow{2}{*}{ 因子 } & 地域活動 & 0.4909 & 0.2697 & 0.0183 & 0.160 \\
& 資源管理 & 0.4743 & 0.1291 & -0.5124 & 0.000 \\
\hline \multicolumn{5}{l}{ *分散分析の結果 }
\end{tabular}

表 7. 各類型の平均因子得点 $(40 \cdot 50$ 代)

\begin{tabular}{l|c|ccc|c}
\hline \multicolumn{2}{l|}{} & $\begin{array}{c}\text { 類型A } \\
(\mathrm{n}=6)\end{array}$ & $\begin{array}{c}\text { 類型 } \mathrm{B} \\
(\mathrm{n}=5)\end{array}$ & $\begin{array}{c}\text { 類型C } \\
(\mathrm{n}=5)\end{array}$ & P值 \\
\hline \multirow{2}{*}{ 因子 } & 地域活動 & 0.0553 & -0.1843 & -0.8039 & 0.002 \\
& 資源管理 & 0.1466 & -0.1527 & -0.7188 & 0.000 \\
\hline \multicolumn{4}{c}{ *分散分析の結果 }
\end{tabular}

表 8. 各類型と集落特性の関係 $(60 \cdot 70$ 代)

\begin{tabular}{|c|c|c|c|c|}
\hline & & 類型 1 & 類型 2 & 類型 3 \\
\hline \multirow{3}{*}{$\begin{array}{l}\text { 人口 } \\
\text { 規模 }\end{array}$} & 総戸数 & 48 & 42 & 28 \\
\hline & 総人口 & 140 & 129 & 85 \\
\hline & 農家率（\%) & 55.8 & 52.1 & 61.2 \\
\hline \multirow{2}{*}{$\begin{array}{l}\text { 人口 } \\
\text { 動態 }\end{array}$} & 人口増減率 $(\%)$ & -5.0 & -2.2 & 1.8 \\
\hline & 農家人口増減率（\%) & -8.2 & -6.5 & -10.7 \\
\hline \multicolumn{2}{|c|}{ 集落活動の活性度（5段階評価） } & 3.72 & 3.28 & 3.35 \\
\hline
\end{tabular}

表 9. 各類型と集落特性の関係 $(40 \cdot 50$ 代)

\begin{tabular}{|c|c|c|c|c|}
\hline & & 類型A & 類型B & 類型 $\mathrm{C}$ \\
\hline \multirow{3}{*}{$\begin{array}{l}\text { 人口 } \\
\text { 規模 }\end{array}$} & 総戸数 & 53 & 38 & 29 \\
\hline & 総人口 & 156 & 120 & 93 \\
\hline & 農家率（\%) & 55.0 & 58.3 & 53.3 \\
\hline 人口 & 人口増減率（\%） & -2.9 & -3.2 & -6.6 \\
\hline 動態 & 農家人口増減率（\%) & -9.4 & -6.6 & -11.1 \\
\hline \multicolumn{2}{|c|}{ 集落活動の活性度（5段階評価） } & 3. 19 & 3.33 & 3. 38 \\
\hline
\end{tabular}

2，類型 3 の間では，あまり差は見られない。この ことから，集落活動はある程度の活発さがあって， はじめて $60 ・ 70$ 代の「地域活動」に関する知識の 得やすさに影響すると考兄られる。

次に, $40 \bullet 50$ 代について分析する.「地域活動」「資 源管理」に関する知識をともに得やすい類型 Aから, ともに得にくい類型 C にかけて, 総戸数は 53,38 , 29 ，総人口で $140 ， 129 ， 85$ と人口規模が小さくな 
る傾向にある.このことより, 集落の人口規模が大 きくなる活ど，地域ナレッジを得やすいことがわ かった。 その一方で, 人口動態では, 人口増減率は 類型 A で $-2.9 \%$ ，類型 B で-3.2\%，類型 C で-6.6\% と知識を得やすい類型ほど，人口減少が低い結果と なり，60・70 代とは逆の結果が得られた。 また， 60 ・70 代で知識の得やすさと関係性がみらえた, 集落活動の活性度は類型 $\mathrm{A}$ から類型 C にかけて, 3.19，3.33，3.38 とあまり差は見られなかった。

\section{4. 考察}

以上の結果から，まず本稿によって明らかになっ た知見として，集落によって地域ナレッジの共有の 程度（得やすさ）が異なり，集落特性と知識の共有 の関係が示された点である. 以下，知識の共有と集 落特性の関係について設定した $3 つ の$ 仮説について 検証結果をまとめ, 考察を加えるとともに, 地域ナ レッジ共有の課題について考察する。

仮説（1）集落の人口規模と知識の得やすさの関 係では， $40 ・ 50$ 代， 60 ・70 代ともに，人口規模が 大きい集落汪ど，知識を得やすいことがわかった，

仮説（2）集落の人口減少と知識の得やすさの関 係については，40・50 代では，人口減少が激しい 集落ほど，知識は得にくい結果となったが，60・70 代では, 逆に人口減少が激しい集落ほど, 知識は得 やすいといら結果となった。

仮説（3）集落活動の活発さと知識の得やすさの 関係では，60・70 代の住民では，集落活動が活発 なほど，地域ナレッジは得やすいことがわかり，特 に「地域活動」に関する知識を得やすいことが言兄 た. $40 ・ 50$ 代では, 知識の得やすさとの関係はみ られなかった。

以上の関係性をもたらす要因について考察する と，まず，集落の人口規模では，人口規模が大きい ほぞ，住民の知識の獲得先が多くなり知識を得やす くなることが大きな理由として考光られる.しかし， 小規模集落の方が住民同士のつながりが強く，地域 ナレッジが得やすいという捉え方も可能であり，こ の点については今後の質的な調査の追加による検討 が必要と考光る.

また，人口動態に関する結果について，人口減少 が激しいほぞ，40・50 代で地域ナレッジを得にく いことは，急激な人口減少が，地域ナレッジのやり
取りの機会の減少に繋がっていることを示唆するも のである. しかしながらその一方で, $60 ・ 70$ 代では， 人口減少が激しい集落ほど，知識を得やすい結果と なっている。これは，60・70代は，どちらかとい えば既に地域ナレッジを有する世代であることか ら，人口減少がより密なやり取りを可能としている ことが考えられる。

集落活動の活性度は，60・70 代の得やすさと関 係はあるが，40・50 代とは関係が確認されなかった。 これは，60・70 代は，基本的に勤めを辞めており， 集落活動に積極的にかかわることが可能であること から影響を受けやすく，一方の $40 ・ 50$ 代は，仕事 等により積極的に活動に参加できないためと考兄ら れる。

最後に，以上の結果から事例地域に抢ける地域ナ レッジ共有の課題についてまとめる。まず，人口規 模の小さい集落では，40・50 代だけでなく，集落 運営の中心である 60 ・70 代に打いても知識の共有 が十分に打こなわれていない，逆に，ある程度の規 模を維持している集落では，40・50 代，60・70 代 ともに地域ナレッジの共有は他の集落と比べ進んで いる．対策としては，次世代の担い手であり全般的 に知識を得にくくなっていると懸念される $40 ・ 50$ 代が知識を得やすい環境を整えていくことが重要で ある。具体的には，知識の獲得先を増やす，獲得す る機会を設けることが考兄られるが，人口規模が小 さい集落では，60・70 代に扔いても知識共有が十 分でない可能性もある. 今後，単一集落にて対策を 立てるだけでなく，複数集落など広域での対策も視 野に入れて考光る必要がある。

今後，地域ナレッジの得やすい集落と得にくい集 落とで事例的研究を行い，今回関係が示された集落 活動の活性度や集落規模がどのよらなメカニズム で，住民の知識の得やすさに影響を与えているのか を明らかにすることが研究課題として残された。

注 1）暗黙知とは，狭義では認知のプロセスであり，言 語化や図式化が難しい知識と定義されるが，本研 究では, 知識経営論で野中ら [4]が示した, 「経 験や勘に基づく知識で, 形式知化がされていない 知識」といら広義の定義を援用する。

2）野中ら [4] は, 文脈に依存した知識を共有するには, 相互関係を通じた文脈を共有することが必要だと述 べて抒り，相互関係を築く空間が場だとしている。 
3）本稿は，既存のナレッジの共有・伝承に焦点を絞つ て抢り，新しいナレッジの創出といら側面には, 言及していない。

4）本調査では, 地域ナレッジ以外の調査も兼礼て実 施して扣り，本稿で分析に用いた項目はアンケー 卜票を構成する項目の 1 部である.

5）仮説の検証は，地域ナレッジは住民の世代が高く なるほど得やすくなる傾向（中塚ら［1]）がある ため，40・50 代，60・70 代の 2 世代にわけておこ なった，集落単位で検証を行わなかったのは，世 代ごとの知識の得やすさを考慮した集落の類型化 を扣こなら場合，類型あたりのサンプル数が少な くなり，分析結果に十分な信頼性が得られないと 判断したためである.

\section{参考文献}

[1] 中塚雅也・星野 敏「農村生活に関する知識 への認識と共有化の課題一兵庫県篠山市 K 地区 を事例として一」,『農業経営研究』，46，2008， pp. 160-164.

［2］深町拓司・星野 敏「地域資源管理に関する 知識の偏在と継承に関する研究一兵庫県稲美 町のため池管理を対象として一」、農村計画 学会誌』, 25, 2006, pp. 359-364.

［3］菅原麻衣子・藍澤 宏・井橋朋子「農山村地 域に打ける住民の地域社会に関する知識保有 と活用実態 一高齢社会型の地域社会に打け る高齢者の役割と参画一」, 『農業経営研究』, 24, 2005, pp. 271-276.

[4] 野中郁次郎・竹内弘高, 『知識創造企業』, 東 洋済新聞社， 1996. 